\title{
WestVirginiaUniversity
}

THE RESEARCH REPOSITORY @ WVU

Graduate Theses, Dissertations, and Problem Reports

2006

\section{Student beliefs and self-reported juvenile deliquency: A test of general strain theory}

Jacqueline Nicole Canady

West Virginia University

Follow this and additional works at: https://researchrepository.wvu.edu/etd

\section{Recommended Citation}

Canady, Jacqueline Nicole, "Student beliefs and self-reported juvenile deliquency: A test of general strain theory" (2006). Graduate Theses, Dissertations, and Problem Reports. 4217.

https://researchrepository.wvu.edu/etd/4217

This Thesis is protected by copyright and/or related rights. It has been brought to you by the The Research Repository @ WVU with permission from the rights-holder(s). You are free to use this Thesis in any way that is permitted by the copyright and related rights legislation that applies to your use. For other uses you must obtain permission from the rights-holder(s) directly, unless additional rights are indicated by a Creative Commons license in the record and/ or on the work itself. This Thesis has been accepted for inclusion in WVU Graduate Theses, Dissertations, and Problem Reports collection by an authorized administrator of The Research Repository @ WVU. For more information, please contact researchrepository@mail.wvu.edu. 


\title{
STUDENT BELIEFS AND SELF-REPORTED JUVENILE DELIQUENCY: A TEST OF GENERAL STRAIN THEORY
}

\author{
By \\ Jacqueline Nicole Canady \\ Thesis submitted to the Eberly College of Arts and Sciences \\ At West Virginia University in partial fulfillment of the requirements \\ for the degree of \\ Master of Arts \\ In \\ Applied Social Research
}

Approved by

James Nolan PhD., Chair

Ronald Althouse $\mathrm{PhD}$.

Jennifer Steele PhD.

Department of Sociology and Anthropology

Morgantown, West Virginia 2006

Keywords: School Delinquency, Strain Theory, Education Longitudinal Survey Copyright 2006 Jacqueline Canady 


\begin{abstract}
Student Beliefs and Self-Reported Juvenile Delinquency: A Test of General Strain Theory
\end{abstract}

\title{
Jacqueline Nicole Canady
}

The purpose of this study is to test Robert Agnew’s General Strain Theory. The researcher applied the theory to secondary data of high school sophomores utilizing Educational Longitudinal Survey of 2002. The study sought to understand whether Agnew's strain theory is applicable to high school environments. The findings indicate some support for Agnew’s Revised Strain Theory. Conversely, sex is substantially insignificant concerning self-reported juvenile delinquency within schools. Furthermore, without accounting for students’ upbringing and socioeconomic background Agnew’s General Strain Theory cannot explain differences in race and delinquency. In conclusion, the study suggests further research of Agnew’s theory, concerning both race and sex. 


\section{Dedication}

I would like to dedicate this work to my parents, Herman G., and Barbara L. Canady 


\section{Table of Contents}

Abstract $\quad$ ii

Dedication iii

List of Tables vii

Statement of Problem $\quad 1$

Purpose of Study 1

Theoretical Perspective and Review of Literature 2

$\begin{array}{lc}\text { Significance of Study } & 8\end{array}$

Hypotheses $\quad 9$

$\begin{array}{ll}\text { Hypothesis } 1 & 10\end{array}$

$\begin{array}{ll}\text { Hypothesis } 2 & 10\end{array}$

$\begin{array}{ll}\text { Hypothesis } 3 & 11\end{array}$

Hypothesis $4 \quad 11$

$\begin{array}{ll}\text { Methods } & 12\end{array}$

$\begin{array}{ll}\text { Data } & 12\end{array}$

Previous Research Using Educational Longitudinal 2002 Data 13

$\begin{array}{ll}\text { Sample } & 13\end{array}$

$\begin{array}{ll}\text { Study Design } & 14\end{array}$

$\begin{array}{ll}\text { Measures } & 15\end{array}$

$\begin{array}{ll}\text { Definition of Terms } & 16\end{array}$

$\begin{array}{ll}\text { Strain } & 16\end{array}$

$\begin{array}{ll}\text { Objective Strain } & 16\end{array}$

Subjective Strain 16 
$\begin{array}{ll}\text { Belief } & 16\end{array}$

$\begin{array}{ll}\text { Positive Student Belief } & 17\end{array}$

$\begin{array}{ll}\text { Negative Student Belief } & 17\end{array}$

$\begin{array}{ll}\text { Attachment } & 17\end{array}$

$\begin{array}{ll}\text { Involvement } & 17\end{array}$

$\begin{array}{ll}\text { Commitment } & 18\end{array}$

$\begin{array}{ll}\text { Victim } & 18\end{array}$

Delinquency/Deviance 18

$\begin{array}{lr}\text { Independent Variables } & 18\end{array}$

$\begin{array}{ll}\text { Demographic Variables } & 18\end{array}$

Indexes of Independent Variables $\quad 19$

$\begin{array}{ll}\text { Positive Student Views } & 20\end{array}$

$\begin{array}{ll}\text { Negative Student Views } & 20\end{array}$

$\begin{array}{ll}\text { Student Attachment } & 21\end{array}$

Academic Support (Involvement) $\quad 21$

$\begin{array}{ll}\text { Victim } & 21\end{array}$

Views of Rules and Regulations $\quad 22$

Commitment 22

Dependent Variables $\quad 22$

$\begin{array}{ll}\text { Interpreting Variables } & 23\end{array}$

$\begin{array}{ll}\text { Data Analysis } & 24\end{array}$

$\begin{array}{ll}\text { Delimitations and Limitations } & 24\end{array}$

$\begin{array}{ll}\text { Findings } & 25\end{array}$ 


\section{List of Tables}

1. Bivariate Logistic Regression Test 26

2. Multivariate Logistic Regression for Sex and Race 28

3. Multivariate Logistic Regression Test 30 


\section{STATEMENT OF THE PROBLEM}

The problem of juvenile delinquency and poor student behavior has long been a discussion in the American education system. More and more, we hear of reports in the news of student violence and drug use. School shootings and drug busts have become such a problem, that school often post security guards to maintain student behavior. Behavior management of students has become increasingly a priority in the American education system. As a kindergarten aide, the researcher personally witnessed teachers spending time managing student behavior. The researcher began to notice that the teacher routinely disciplined certain students while other students rarely received punishment. This led the researcher to question reported delinquency of students and its causes. How can society decrease delinquent behavior in schools? We must first start by recognizing what causes delinquent behavior. Once educators have garner insight concerning what kinds of strain that school environments create, educators and parents can adapt new policies to decrease student disciplinary problems.

\section{PURPOSE STATEMENT}

The purpose of this study is to test and elaborate on Robert Agnew’s revised strain theory of juvenile delinquency within the context the education system. The data employed is from the National Educational Longitudinal Study, 2002 conducted by the National Center for Education Statistics base year to relate students’ perceptions of school to juvenile delinquency. Using Agnew’s General Strain Theory as the basis of this research, students, attitudes, values, and perceptions to their behavior are related to delinquency. 


\section{THEORETICAL PERSPECTIVE AND REVIEW OF LITERATURE}

\section{Introduction}

The theory of delinquency in this study is Revised General Strain Theory. Robert Agnew developed the theory in the late 1980's response to the criticism of Strain Theory, which developed by Robert K. Merton developed in the 1930’s. First, I will outline the overall theory; second, I will discuss the use of the theory in relevant research; third, I will give an overall analysis as to the strengths and weaknesses of these studies, and finally, I will discuss how the theory applies to this study.

\section{History of General Strain Theory}

American sociologist Robert K Merton devised strain theory in the 1930’s utilizing Emile Durkheim's concept of the anomie in order to explain acts of deviancy which may later lead to criminal acts (Merton 1938). Merton’s strain theory focused on the "reasons behind the increased likelihood of deviance that results from the breakdown of society. ...The decrease in societal regulations creates an increased pressure to commit deviant acts” (Agnew and Passas, 1997:2). Unlike Durkheim, Merton did not believe that the cause of anomie is social change but instead by present strains in society's social system. According to Merton, it is

\footnotetext{
“...social structure that holds out the same goals to all its members without giving them equal means to achieve them; it is this lack of integration between what the culture calls for and what the structure permits that causes deviant behavior" (1968).
}

Deviance is a symptom of the social structure. Merton took Durkheim's notion of anomie to describe the breakdown of the normative system (Merton 1938). Merton explains why crime is more likely to occur in low level of socio-economic environments. According to Merton, lower classes are the most likely to suffer from strain because lower classes will continue to strive for their aspirations despite failure to achieve them 
(Merton 1938). The cause of strain (social anomie) is a result of constant failures, because not everyone has equal access of achieving their aspirations (Merton 1938). According to Merton, there are five modes of adaptation to strain. These five modes relate to how a person attempts to achieve his/her goals. The first mode of adaptation is conformist, in which an individual accepts the goals and means of achieving them (Demelo 1999). The second mode is the innovator, in which the individual rejects the means but accepts the goals. The third mode of adaptation is the ritualist, in which the individual rejects the goals but accepts the means. The fourth is the retreatist, in which the individual both rejects the goals and the means. The final mode of adaptation is the rebel, in which an individual revolts from the means and creates a new goal for himself/herself (Demelo 1999).

By the 1980's, Merton's Strain Theory was increasingly criticized on the basis that the variables were either unrelated or weakly related (Agnew and White 1992: 475). One of the criticisms against Merton's Strain Theory argues that the theory is so large, that "researchers have little guidance as to the specific types of strain to examine in their research” (Agnew 1992: 320). One criticism of Strain Theory has been the disjunction between aspirations and expectations. According to Merton's Strain Theory, one would expect delinquency to be greatest when aspirations are high and expectations low, but previous research reveals that this is not the case. Prior research has shown that individuals with high expectations (middle class) are just as likely to commit crime as the lower classes (Agnew 1985: 152). Merton’s Strain Theory predicted that delinquency is concentrated in the lower classes. However, previous research contradicts this prediction revealing that delinquency is just as common in the middle classes (Agnew 1985: 152). 
Thus, general strain theory needs to pinpoint the types of strain that are more likely to lead to delinquency. Strain theory underwent revisions in response to the criticisms. By 1992 Robert Agnew, a criminologist and sociologist, broadened strain theory to focused on three causes of strain; first, "failure to achieve positively valued goals, actual or anticipated, second, removal of positively valued stimuli, and third, actual or anticipated presentation of negative stimuli” (Agnew 1992).

Agnew's General Strain Theory

Agnew's general strain theory differs from Merton's strain theory by “emphasizing the role of the individual's affective responses to negative life experiences in fostering deviant behavior" (Aseltine, Gore and Gordon 2000: 256). The link between strain and delinquency is that strain can cause negative feelings within the individual making them angry and wanting to act out in terms of crime. This happens because if an individual has negative relations with others and the individual is not treated in a way he/she desires, anger will result. According to Agnew, it is anger and frustration that creates the strain that will lead to crime or delinquency. This anger towards the environment may make the individual want to take revenge on society. The individual may justify crime, or as Agnew put it "an increase in strain would lead to an increase in anger, which may then lead to an increase in crime” (1992: 61). According to Agnew there are three major types of strain:

"(a) those that jeopardize the achievement of positively valued goals, (b) those that remove or threaten to remove positively valued stimuli, and (c) those that present one with negatively valued stimuli” (Hoffman and Su 1997: 47).

Factors and events that cause strain and are strongly related to crime are: parental rejection, supervision that is very strict and harsh, child abuse and neglect, negative secondary school experiences, work in secondary labor market (especially if the work is 
unpleasant or repetitive), homelessness (especially youth homelessness), abusive peer relationships (especially among youth), criminal victimization, experiences with prejudice, and discrimination based on ascribed characteristics (like race and ethnicity) and finally the failure to achieve core goals that are not the results of conventional socialization and that are easily achieved through crime (crime to get money) (Agnew 2000: 343-347). Agnew's list builds on classic strain theorists by focusing on negative relationships and arguing how "adolescents are pressured into delinquency by the negative affect resulting from such relationships” (Agnew and White 1992: 476). According to Agnew, the revised strain theory is superior to previous strain theories because first,

“...the research on the disjunction between aspirations and expectations does not challenge the revised theory, since the revised theory is not based on the idea that delinquency results from the frustration of future goals. Second, revised strain theory is able to explain the prevalence of middle-class delinquency, since middle class adolescents may encounter aversive situations from which they cannot escape" (Agnew 1985: 162).

In addition, Agnew states that other factors that determine delinquent behavior were never pinpointed by previous strain theories. “...Strains are most likely to lead to crime when they are (1) seen as unjust, (2) are seen as high in magnitude, (3) are associated with low social control, and (4) create some pressure or incentive to engage in criminal coping (Agnew 2000: 351).

However, certain coping resources can offset delinquent behavior. An individual who has social supports will be better able to cope. An individual will be less likely to engage in delinquent acts if they have social coping mechanisms. Society can also “'influence individuals' behavior by indicating the importance that should be placed on certain goals and determination of what is adverse and what is not" (Agnew 1992:72-73). 
Furthermore, if an individual has high goals for him/herself, but does not have alternative goals to fall back on then that may lead to delinquent behavior (Agnew 1992: 72-73).

Overall, delinquent acts are lessened by reducing negative relationships and negative reactions from others, by providing social supports, and providing alternative goals for the individual to fall back on.

In order to test, Agnew’s General Strain Theory, Agnew suggests that researchers first identify an approach to measure strain. First, the subjective approach is when the researcher directly a respondent if they disliked their treatment. The second is the objective view in which the researcher identifies pre-determined sources of strain (Agnew 2000).

\section{Previous Research Utilizing Strain theory}

Robert Agnew provides the first examination of revised strain theory. Agnew and White conducted a test of general strain using data from the Rutgers Health and Human Development Project to measure failure to achieve positively valued goals. Agnew and White found support for General Strain Theory. Another study that utilizes strain theory is a quantitative study concerning strain theory's approach to families and delinquency. Agnew theorized that his General Strain Theory would be compatible with the research on the causes of poor parenting. Agnew, Rebellon and Thaxton's findings were that parental strain might lead to negative affect and poor parenting, which in turn is a major source of strain. However, there is evidence of gender, age, and race/ethnic differences in the types of strain experienced and reaction to strain (Agnew, Rebellon, and Thaxton 2000: 132). 
Nicole Piquero and Miriam Sealock expand upon Agnew’s revised strain theory. They investigated the "generality of general strain theory by exploring the operation of strain in an offending population” (Piquero, and Sealock 2000: 449). The data obtained in the study came from interviews (approximately 150 youths) conducted on research staff members at a large United States university. The youths have been adjudicated for a variety of offenses, and all had been identified as chemically abusing or dependent (Piquero, and Sealock 2000: 449). Piquero and Sealock created an Additive Strain Index that measured the amount of physical abuse directed to youths, the amount of physical abuse directed toward others, and the amount of emotional abuse directed to youths (2000: 457). The findings of Piquero and Sealock's research reveal encouraging support for revised strain theory; however, variables such as anger did not predict crimes such as vandalism. The researchers concluded that there is a need for more research examining General Strain Theory.

Hoffman, Cerbone, Aseltine, Gore, and Gordon, examine research based on stressful life events and adolescent delinquency. Hoffman and Cerbone probe potential pathways of delinquency escalation in adolescence. The study hypothesizes that if adolescents experience persistent stressful events, over time it could lead to an escalation of delinquency. Drawing on Agnew's strain theory, and utilizing data from the Family Health Study, an empirical study demonstrated that stressful life events are indeed associated with the escalation of adolescent delinquency. Aseltine, Gore, and Gordon’s research analyze life stress and revised strain theory by empirically testing anger and anxiety as a cause of strain. The results of their study were not promising, revealing limited support for general strain theory (Aseltine, Gore, and Gordon 2000: 270). 
One study regarding sex differences and General Strain Theory is a research by John Hoffman and S. Susan Su, in which they assess sex-specific effects of stressful life events on delinquency and drug use (Hoffman and Su 1997: 46). Hoffman and Su used two waves of data from 11 to 17 year olds adolescents who participated in the High Risk Youth Study (N=803). Their focus was sex-differentiated responses to stress. Based on both empirical and theoretical methods, the data demonstrates that females and male adolescents react differently to stress (1997: 69). The findings reveal that stressful life events among female and male adolescents are similarly associated with delinquency and drug use (Hoffman and Su 1997: 70).

Agnew’s theory applies to this study in order to investigate how students' perceptions of school and academic goals either increase or decrease the amount of delinquency in schools. The expectation of the independent variables of positive and negative views of school is they will influence the dependent variable of reported delinquency, because if a student has positive views of school and good social networks then they are less likely to engage in delinquent behavior and vice versa. All the studies using General Strain Theory noted that there was a need for more research. This research will add to the growing body of literature concerning General Strain Theory.

\section{SIGNIFIGANCE OF RESEARCH}

A study concerning how Agnew’s theory applies to school delinquency is useful to future research because, first, it contributes to a relatively recent theory. Agnew revised Strain theory in the early 1990’s. Thus, the amount of research conducted concerning General Theory of Strain has been limited. This study will add to the burgeoning research being contributed to this subject. 
Second, there is little research concerning Agnew’s revised theory within high schools. Although Social Control Theory and Merton's Strain Theories have been applied to the research of juvenile delinquency for decades, General Strain Theory has not been as heavily applied to delinquency within schools. In addition, most previous research done concerning juvenile delinquency and strain theory focused on limited populations. The ELS 2002 data set is a broad national school population, and studies utilizing strain theory on a broad population has been lacking, thus this research will contribute further to a review of literature. A third contribution of this study is that the study uses recent data. Therefore, the results are applicable to the present, whereas older studies might already be dated.

Furthermore, this study is significant in how it takes into account both student views and whether the student was a victim of a crime. Thus, this study looks at both confrontation with negative stimuli (student as a victim), and the failure to achieve positively valued goals (expressed with their views).

\section{Hypotheses}

Based on Robert Agnew's General Strain Theory, the researcher tested four hypotheses using bivariate and multivariate analysis to determine if negative stimuli causes strain which leads to delinquency.

\section{Hypothesis 1}

If students who have negative views of their school life then the students will suffer from greater strain, which lead to delinquency. Thus, students are more likely to engage in reported delinquency when controlling for sex and race. 
Null hypothesis: Students who have negative views of their school life will show no increase in juvenile delinquency.

Hypothesis 1: Positive Relationship

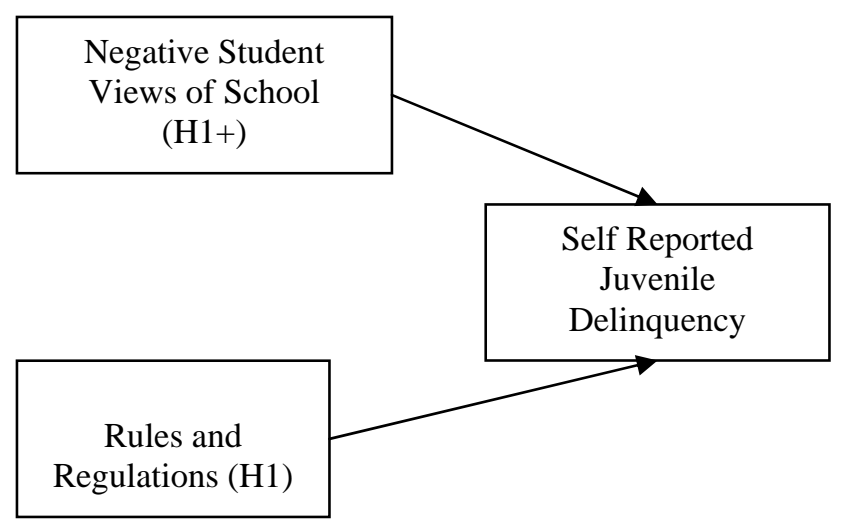

\section{Hypothesis 2}

If students are attached to their school environments and are involved in school activities then students are less likely to suffer from strain and thus will have less reported delinquency when controlling for sex and race.

Null hypothesis: Students who are attached to their school environments and are involved in school activities will not lead to a decrease in juvenile delinquency.

Hypothesis 2: Negative Relationship

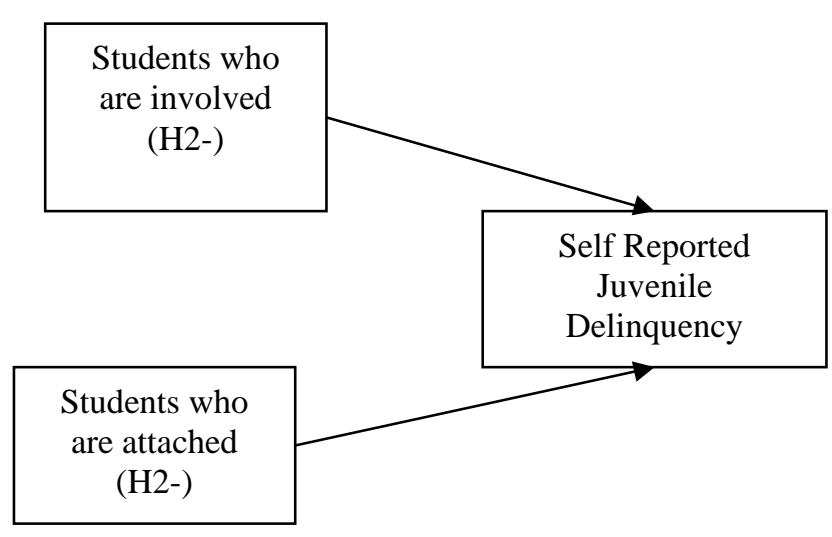




\section{Hypothesis 3}

Students who have been victimized at school and who have negative views of their school are more likely to experience strain, which leads to a greater probability of juvenile delinquency when controlling for sex and race.

Null hypothesis: Students who have been victimized at school and who have negative views of their school will not lead to an increase in juvenile delinquency.

Hypothesis 3: Positive Relationship

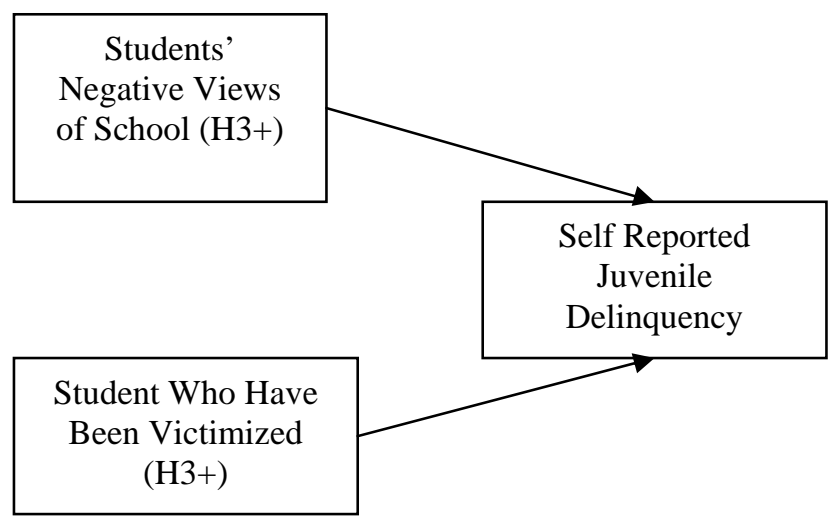

\section{Hypothesis 4}

Students’ positive views of school and students' commitments to school ease social strain and thus contributes to a decrease in student delinquency when controlling for sex and race.

Null hypothesis: Students’ positive views of school and students commitments to school will not lead to a decrease in juvenile delinquency. 
Hypothesis 4: Negative Relationship

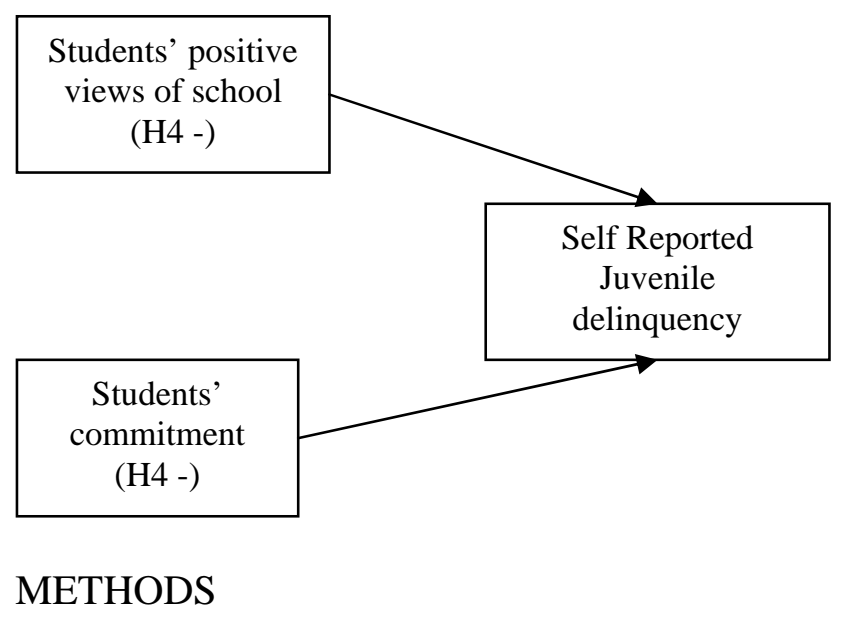

Data

The data of this study is from the 2002 base year of Education Longitudinal Study of 2002 (ELS:2002), which is cross-sectional survey that monitors' the transitions of a national sample of high school students as they progress from their sophomore year through their following high school education and beyond (Ingels 2004: 1). The data set is “designed to provide trend data concerning critical transitions experienced by students as they enter post-secondary education and the labor force” (Ingels et al. 2004:1). The focus of ELS 2002 base-year is to provide descriptive information concerning the nations' high school sophomores in the spring term of 2001-2002 school years (Ingels et al. 2004:2). The ELS 2002 has a distinctive features: "it is a multilevel study in which information is collected from multiple respondent populations including students, teachers, and parents.” (Ingels et al. 2004:1).

The first year data collection gathered information concerning students’ achievement about their school attitudes and experiences of their schools. This present study uses the 2002 base year data. The base year data contained questions concerning 
students' achievements, attitudes and experiences that were used as variables concerning beliefs, attachment, involvement, commitment, and delinquency.

\section{Previous Research}

Because the data in this study have only been available since 2004, there has been few published research utilizing ELS 2002 data set. Two recent publications utilizing the ELS 2002 data set are both initial results from the National Center of Educational Statistics. One of the first studies published using ELS 2002 data is a profile of the “American High School Sophomore Class in 2002.” These results presented findings concerning the character and experiences of high school sophomores. Furthermore, the report gives descriptive information about the students' demographics. "In addition, it examines the cohort’s socio-demographic characteristics, school experiences, participation in extracurricular activities, time use, tested achievement in reading and mathematics, and educational expectations and plans”(Ingels et al. 2005:1). Another, report from the National Center of Educational Statistics examines the first follow up of the ELS 2002 longitudinal study and provides a profile of the now high school seniors. Unlike the prior report, this report includes students’ plans after high school, their expectations for eventual educational attainment and how the students' decided to chose a post-secondary institution (Ingels et al. 2005: 1).

\section{Sample}

The sample sizes for the ELS 2002 Base Year data set included 752 schools and over 15,000 participating students. The data stratified 752 schools by urban, suburban, and rural, in four U.S. levels of geography (East, South, Midwest, and West) and if the school is a public or private institution. The students sampled were all $10^{\text {th }}$ graders and 
with an English and Mathematics course. The sample size of students was comprised of 15,362 (a weighted response rate of $87 \%$ of the original sample of 17,591 eligible students) with some groups (e.g. Asians) being over sampled to compensate for unequal probabilities of schools (Ingels et al. 2004: 43). Students with mental disabilities and not proficient in English were not included in the sampling.

\section{Study Design}

The Educational Longitudinal Study 2002 obtained base-year data by a probability questionnaire of five separate questionnaires (one each for students, teachers, parents, administrators, and librarians) 15,362 students, 7135 teachers, and 13,488 parents. The questionnaire included both an academic assessment of students, (which measured achievement in reading and mathematics) and a student questionnaire. The questionnaire gathered information about the students' background, school experiences, activities, plans and goals for future employment, out of school experiences, and psychological orientation towards learning (Ingels et al. 2004:28).

The ELS 2002 is a longitudinal data set "in which waves of individual data are used in analysis” (Ingels et al. 2004:12). Because the research was conducted as a longitudinal study, the researchers sought to select items that would be useful in predicting outcomes of future survey waves (Ingels et al. 2004: 12). Furthermore, the survey gathered cross-sectional data "that could be used with intercohort comparison with past studies or linkage to current collection data efforts” (Ingels et al. 2004:12). ELS 2002 questionnaires sought to be consistent with previous educational longitudinal questionnaires, especially the National Educational Longitudinal Study of 1988 (Ingels et al. 2004:30). 
The researcher choose one parent of each participating sophomore to fill out a parental survey concerning parental aspirations for the child, as well as home background, prior education, and socio-economic resources (Ingels et al. 2004:28). Teachers’ surveys included evaluations of students enrolled in English or mathematics; the teacher provided evaluations for the students, the teachers' background and activities (Ingels et al. 2004: 28).

Measures

The ELS 2002 student questionnaire was a 45-minute self-administered survey. Sophomore participants completed the questionnaire in a "group administration in the classrooms of their schools” (Ingels et al. 2004: 33). Furthermore, the student questionnaire is divided into seven sections: “(1) locating information, (2) school experiences and activities, (3) plans for the future, (4) non-English language use, (5) money and work, (6) family, and (7) beliefs and opinions about self” (Ingels et al. 2004: 17).

The longest section of the student questionnaire was that on school experiences and activities. This particular section queries the student on their school climate, student recognition, school disengagement (i.e. delinquency such as skipping school, etc), perception of high school program placement, attitudes and motivation for attending school, learning environment, importance of grades, time spent on reading and extracurricular activities, and future plans after high school (Ingels et al. 2004: 17). This particular module relates to the study in that by obtaining information concerning the student attitudes toward school, one can measure the causes of strain between students. 
The final module inquires as to the beliefs and opinions about self. ELS 2002 student questionnaire utilizes psychological scales that have been adapted from PISA 2000 (Ingels et al. 2004: 18). The questionnaire’s responses are scaled from one to four with each representing: (1) Strongly agree, (2) Agree, (3) Disagree, and (4) Strongly disagree. The psychological scales of the data set relate to my study in measuring how individuals cope with strain. Do students' beliefs contribute or cause strain, which in turn could create delinquency?

Operalization of Terms

\section{Strain}

The operational definition of strain "refers to 'relationships in which others are not treating the individual as he or she would like to be treated,'” which creates stress felt by the individual (Agnew 2000: 320).

Objective Strain. Objective strain refers to the "events or conditions that are disliked by most members of a given group. So, if we state that an individual is experiencing objective strain, we mean that he or she is experiencing an event or condition that is usually disliked by members of his or her group”. (Agnew 2000: 320).

Subjective Strain. Subjective strain "refer to events or conditions that are disliked by people who are experiencing (or have experienced) them. So, if we state that individuals are experiencing subjective strain, we mean that they are experiencing an event or condition that they dislike” (Agnew 2000: 320).

\section{Belief}

The operational definition of belief is based on Travis Hirschi’s Social Bond Theory concerning society’s value system (i.e. respect for laws). "Hirsch argued that people who 
live in common social settings share similar human values. If such beliefs are weakened ...one is more likely to engage in anti social acts. Also, when the bond weakens, people are likely to commit delinquent acts (Demelo 1999). A strongly held opinion by an individual who influences another individual's viewpoint and thus the interaction that individual has within an institution. (Hirschi 1969).

\section{Positive Student Belief}

The operational definition of positive student beliefs is favorable opinions that the student thinks about himself/herself, teachers, and the school environment. These beliefs strongly influence student interactions with teachers and within the school institution.

\section{Negative Student Belief}

The operational definition of negative student beliefs is negative opinions that the student thinks about himself/herself, teachers, and the school environment.

\section{Attachment}

The operational definition of attachment refers to one's interest in others and acceptance of social norms. Hirschi also asserted that attachment for other human beings also explains the development of social conscious. It can take three forms: parents' institutions or peers (Hirschi 1969).

\footnotetext{
"While examining the bond with school, Hirschi found that an inability to do well in school is linked with delinquency, through a series of chain events. He argued that academic incompetence leads to poor school performance, which leads to a dislike of school, which leads to rejection of teachers and authority, which results in acts of delinquency. He argued that one's attachment to school depends on how one appreciates the institution and how he/she is received by fellow peers and teachers" (Demelo1999).
}

\section{Involvement}

According to Travis Hirschi, involvement addresses "a preoccupation in activities that stress the conventional interests of society" (Delmelo1999). Involvement in activities 
does not leave any time for acts of deviance since it keeps juveniles from being idle. (Hirschi 1969).

\section{Commitment}

According to Hirschi, commitment is a social bond that involves time, energy, and effort placed on conventional lines of action (Hirschi1969). "Hirsch’s control theory holds that people who build an investment in life, property, and reputation are less likely to engage in criminal acts which will jeopardize their social position” (Demelo 1999).

\section{Victim}

The operational definition of a victim is an individual who suffers direct physical emotional or financial harm.

\section{Delinquency/Deviance}

The operational definition of delinquency is behavior that is considered nonconformist to a set of norms that are accepted by society (behavior that is seen as a transgression of what is considered acceptable) (Giddens et al. 2003: 179). Delinquency according to social control theory proposes that if the bonds of relationships (beliefs, commitments involvements and attachments) are strong, then people will choose to conform to social values and not become deviant (Giddens et al. 2003: 179). In this study, the operational definition of delinquency is a failure to follow pre-established rules within a school institution.

\section{Independent Variables}

Demographic variables. The demographic variables analyzed in this study were sex and race. Examining sex discovered that $49.8 \%(n=7646)$ of respondents were male and $50.2 \%(n=7716)$ of respondents were female. The scale measuring sex is $0=$ male 
and 1 = female. For race, the variables analyzed showed that $57.0 \%(n=8757)$ of respondents were white/non-Hispanic, 4.8\% (n= 742) of respondents were multi-racial, 8.0\% $(n=1233)$ of respondents are Hispanic, 6.5\% $(n=1001)$ of respondents are Hispanic (no race-specified), 13.0\% $(\mathrm{n}=2003)$ of respondents are Black or African American (non-Hispanic), 9.5\% $(n=1465)$ of respondents are Asian, and .9\% $(n=131)$ of respondents are American Indian. The analysis categorized the variable of race from last to first.

Indexes of Independent Variables

For the study, the researcher created indexes of variables after examining individual questions in the ELS 2002 questionnaire. I selected questions that I thought closely matched Hirschi's theory of socialization. I grouped different questions around the concepts of socialization, such as belief, attachment, involvement, commitment. In addition, the researcher created an index for students' views on rules and regulations of their school environment, and the victimization of students in order to measure causes of strain.

\section{Belief}

In order to examine the variable of Belief, the researcher divided the variable of into two different variables; one being Positive Student Views of School, and the other being Negative Student Views of School by examining questions concerning student opinions about themselves, their schools, their teachers, and whether those school experiences were good or bad. Note that the title appears to indicate that the absence of one is the presence of another, but that is not the case. Each variable index contains different items to measure Subjective Strain. The researcher measured the variables of 
Positive and Negative Views by how much they disagreed with the statements. For example, in order to measure Negative Views the researcher analyzed how much the respondents disagreed with positive statements. To measure Positive Views, the researcher analyzed how much the respondents disagreed with negative statements. Negative Student Views. For the variable of Negative Student Views, the researcher created an index by adding together results of questions concerning the amount of agreement for the following statements: (1) 'Learns skills for job in school', (2) 'Satisfied by doing what is expected in class', (3) 'Education is important to get a job later', and (4) 'School rules are fair'. The responses are scaled from one to four with each representing (1) Strongly Agree, (2) Agree, (3) Disagree, and (4) Strongly Disagree. Responses from the questions were combined creating a scale from 3-12 ( $\mathrm{N}=14294)$ with a Cronbach’s Alpha of .728, a mean of 5.7015, and a standard deviation of 1.53723

Positive Student Views. For the variable of Negative Student Views, the researcher created an index by adding together results of questions whether students agreed or disagreed with the following statements: (1) 'In class often feels put down by teachers', (2) 'In class often feels put down by students', (3) 'Does not feel safe at this school', (4) 'Disruptions get in way of learning', (5) 'Misbehaving students often get away with it', (6) 'There are gangs in school',(7) 'Racial/ethnic groups often fight', (8) 'Has nothing better to do than school', (9) 'Other students often disrupt class.' The responses are scaled from one to four with each representing (1) Strongly agree, (2) Agree, (3) Disagree, and (4) Strongly disagree. Responses from the questions were combined creating a scale from 9-36 $(\mathrm{N}=13690)$ with an Alpha of .728, a mean of 25.3790, and a standard deviation of 3.82673 
Student Attachment. For the variable of Student Attachment, an index was created by examining the whether students agreed or disagreed with the following questions: (1) BYS20F 'Teachers are interested in students', (2) 'Teachers praise effort', (3) 'Students get along well with teachers', (4) 'Plays on a team or belongs to a club', (5) 'Teachers expect success in school', (6) 'Parents expect success in school', (7) 'The teaching is good ${ }^{1}$. The responses are scaled from one to four with each representing (1) Strongly Agree, (2) Agree, (3) Disagree, and (4) Strongly Disagree. Data from these responses were combined into an index with a range of 7-28 ( $\mathrm{N}=13982)$, an Alpha of .737 , mean of 10.5046, and a standard deviation of 2.28446.

Academic Support (Involvement). The researcher created the variable of Academic Support by examining questions asking respondents if they agreed or disagreed the following: (1)'Won an academic honor', and (2) 'Recognized for good grades'. Responses from these questions were $0=$ No and $1=$ Yes. The responses were added together to create an index with a scale of $0-2(\mathrm{~N}=14546)$, an Alpha of .881 , mean of .8417, and a standard deviation of .85691.

Victim. For the variable of Victim, the researcher created an index by adding together results of questions on whether students agreed or disagreed with the following statements: (1) 'Had something stolen at school', (2) 'Someone threatened to hurt 10th grader at school', (3) 'Got into a physical fight at school', (4) 'Someone hit 10th grader', and (5) 'Someone bullied or picked on 10th grader'. (6) 'Someone forced money/things from $10^{\text {th }}$ grader' The research scaled the responses from one to three with each representing (1) Never, (2) Once or Twice, (3) More than Twice. Responses from these

\footnotetext{
${ }^{1}$ In selecting items to measure the concept of Attachment, the researcher chose indicators that both measure characteristics of the school and characteristics of the student.
} 
questions were added together to create an index with a scale of 0-6 ( $\mathrm{N}=14409)$, an Alpha of .796, mean of 1.3068 , and a standard deviation of 1.50047 .

Rules and Regulations. For the variable of Rules and Regulations, the researcher created an index by adding together results of questions whether students agreed or disagreed with the following statements (1) 'School rules are strictly enforced'.

Responses from this question were scaled from with each representing (1) Strongly agree, (2) Agree, (3) Disagree, and (4) Strongly disagree. Responses from this question had a mean of 2.23, and a standard deviation of .713.

Commitment. The variable of Commitment used the question of 'How much likes school' as an indicator. The researcher scaled the question responses from one to three with each representing (1) Not at all (2) Somewhat (3) A great Deal. Responses from this question had a mean of 2.13, and a standard deviation of .580.

\section{Dependent Variables}

Student Self-Reported Delinquency. The ELS 2002 student questionnaire contained self-reported questions used to measure school disciplinary incidents, concerning whether if the student was in trouble in school and whether if the student had ever broken, school rules and received punishment for such. The researcher examined a series of questions to determine the variable of Student Delinquency. In the study, the researcher analyzed the questions of : (1) 'How many times late for school', (2) 'How many times cut/skip classes', (3) 'How many times absent from school', (4) 'How many times got in trouble', (5) 'How many times put on in-school suspension', (6) 'How many times suspended/put on probation', and (7) 'How many times transferred for disciplinary reasons', and chose them as indications of student delinquency. All the questions contain 
information as to whether the student had broken school rules or been subject to disciplinary action by their school. The students responded to these questions by answering a scale of how many times they committed an act of deviance: (1) never, (2) 12 times, (3) 3-6 times, (4) 7-9 times, and (5) 10 or more times. Responses from the seven questions were added together to create a single index of Self-Reported Delinquency with a scale of 0-7 $(\mathrm{N}=12278)$.

In order, to perform binary logistic regressions, the research recoded each item of Self-Reported Delinquency into a zero/one index. The responses of (1) never, and (2) 1-2 times were recoded to zero (the researcher choose to include 1-2 times as zero since a student who has only gotten in trouble with school authorities once or twice did not necessarily mean that they were delinquent). The researcher recoded rest of the responses as one. Therefore, the variable would measure whether the student either had committed or did not commit deviant behavior in school. It should be noted that that the indicators are not equivalent in relation to their severity, but measure the number of incidents. Response from the Self-Reported Delinquency Index contained a scale of 0-1 ( $\mathrm{N}=14169)$ with $55.4 \%(\mathrm{n}=7843)$ saying they had never or had only once or twice committed a deviant act or received disciplinary action from their school, and 44.6\% ( $\mathrm{n}=$ 6326) saying they had committed a deviant act more than three times.

\section{Interpreting Variables}

The scales measuring Negative Views of School, Positive Views of School, and Commitment are indicative of low values of low levels and high levels are indicative of high values. The researcher coded the variables indexes Attachment, and Rules and Regulations so that low values indicate strong agreement and high values indicate strong 
disagreement. The variables of Student Involvement and Victim are indicative of low values of low levels and high levels are indicative of high values. For the variable of Juvenile Delinquency, zero indicates low values, while high values are indicative by one.

\section{Data Analysis}

The data for this study were analyzed using bivariate logistic regression, and multivariate logistic regression through the Statistical Package for the Social Sciences (SPSS). The researcher used bivariate logistic regression to examine the relationship between each independent variable and dependent variable individually. Multivariate logistic regression was used to examine the relationship between stimuli that can lead to an increase or decrease in juvenile strain. In order to examine the relationship between the demographic variables of Sex and Race, the researcher used multivariate regression. Second, the multivariate regression tests were repeated in four models that correspond to each hypothesis. The first model is a multivariate regression of Sex, Race, Positive Views and Rules and Regulations. Model 2 is a multivariate regression that added Attachment and Involvement to the demographic variables and the previous independent variables. Model 3 incorporates Negative Views and Victimization variables, the demographic variables and the previous variables of model 2. Finally, model four reproduces the previous variables and includes the variable of commitment. Cox and Snell R Square statistics was used to determine the variance.

\section{DELIMITATIONS}

A delimitation of this study is that the study only analyzes high school students. In addition, the study will be limited to using ELS 2002 base year data set. In addition, 
the parental and teacher questions will not be considered since they do not directly pertain to the hypotheses.

\section{LIMITATIONS}

Limitations to the research are that environmental factors such as intimate information concerning the students' background, such as family, neighborhood, and prior delinquency are not included in this current study. Another limitation is that juvenile delinquency is limited to student self-reported delinquency. The students answered on the questionnaire whether they broke in-school rules and whether they were punished for breaking the rules.

\section{FINDINGS}

\section{Relationship between Independent Variables and Dependent Variable}

The researcher used a bivariate test was in order to gain a better understanding of the overall relationship between the dependent and independent variables. Table 1 depicts the results of the bivariate logistic regression analysis of each independent variable and the dependent variable of juvenile delinquency. Analyzing table 1shows that the independent variable of sex is significant, meaning there is a relationship between sex and delinquency. Data indicates that odds of females reporting delinquency are 31\% lower than males. The Cox \& Snell pseudo R square was .008.

When analyzing race, the researcher compared all races with the reference variable white by using bivariate logistic regression. Overall, all racial groups included in the study with the exception of American Indian/ Native American are significant, perhaps because American Indians account for only .9\% $(n=131)$ of respondents. In addition, when compared to the reference variable, all the racial groups included in the 
study, with the exception of Asians, show an increase in the odds of students selfreporting delinquency.

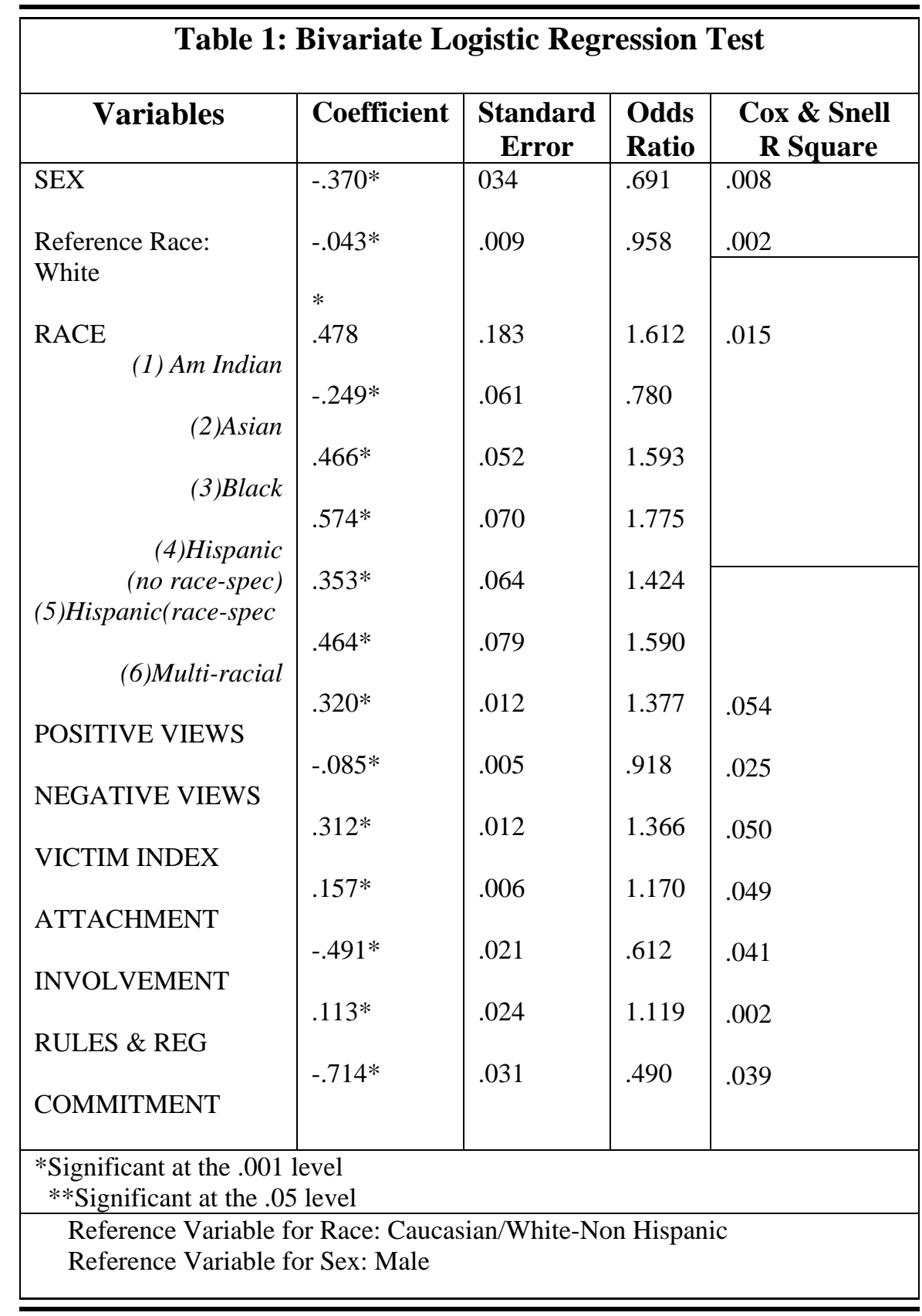

The strongest relationship between race and self-reported juvenile delinquency when compared to the reference variable of whites is Hispanic/no race specified. Odds are $78 \%$ more likely that Hispanics/no-race specified are going to self-report delinquency 
than Whites. American Indian has the second strongest relationship with 61\% more likely to self-report delinquency than Whites (note the relationship is not significant). Blacks are the third strongest relationship; Blacks are 59\% more likely than Whites to self-report delinquency. Asians were the only racial category to report less delinquency than Whites were with odds being 22\% less likely for Asians to self-report delinquency than Whites. The equation produced a Cox \& Snell pseudo R square of .015.

When analyzing the non-demographic independent variables, all the variables with the exception of commitment are significant at the .05 level. The independent variable Negative Views reveal a significant positive relationship with reported juvenile delinquency. For each increment on the Negative Views scale (3 to 12), the odds of students reporting juvenile delinquency increase by $37 \%$. The variable Positive Views reveal a negative relationship. For each increment on the Positive Views scale (9 to 36), the odds of students reporting juvenile delinquency decrease by .08\%.

When examining table 1 , the variable of victim has a positive relationship with reported delinquency. For each increment of the victim index scale (0 to 6$)$, the odds that respondents would report juvenile delinquency increases $37 \%$. Thus, each time students are victims of crime then the more likely students will self-report delinquency.

The variable of attachment in table 1 is reverse coded. For each increment, a student disagrees with the attachment scale (7 to 28) self-reported juvenile delinquency increases $17 \%$. The variable involvement is statistically significant. For each increment of the involvement scale (0 to 2), the odds decrease $39 \%$. The variable rules and regulation indicates that if a student disagrees with rules they are $12 \%$ more likely to selfreport delinquency. When analyzing the variable of commitment in table 1 the 
relationship indicates that the more students agree with commitment then self-reported delinquency decreases 51\%. Overall, the results of table 1 are consistent with the hypotheses.

Multivariate Logistic Regression Analysis. The researcher used multivariate regression (multiple variables within an equation) to analyze the connection between Race and Sex to delinquency. Results of the multivariate regression between Sex and Race and Juvenile Delinquency are presented in Table 2.

\begin{tabular}{|c|c|c|c|}
\hline \multicolumn{4}{|c|}{$\begin{array}{c}\text { Table 2: Multivariate Logistic Regression } \\
\text { for Sex and Race }\end{array}$} \\
\hline \multicolumn{2}{|c|}{ Coefficient } & \multicolumn{2}{|c|}{$\begin{array}{l}\text { Standard Odds } \\
\text { Error } \quad \text { Ratio }\end{array}$} \\
\hline $\begin{array}{l}\text { Sex } \\
\text { Race Reference: White } \\
\text { (1) Am Indian } \\
\text { (2)Asian } \\
\text { (3)Black) } \\
\text { (4)Hispanic(no-spec) } \\
\text { (5)Hispanic(race-spec } \\
\text { (6)Multi-racial }\end{array}$ & $\begin{array}{l}-.376^{*} \\
* \\
.458^{* *} \\
-.254^{*} \\
.472^{*} \\
.575^{*} \\
.355^{*} \\
.467^{*}\end{array}$ & $\begin{array}{l}.034 \\
\\
.184 \\
.061 \\
.052 \\
.070 \\
.064 \\
.080\end{array}$ & $\begin{array}{l}.687 \\
1.581 \\
.776 \\
1.603 \\
1.777 \\
1.427 \\
1.595\end{array}$ \\
\hline Cox \& Snell R Square & \multicolumn{3}{|l|}{.023} \\
\hline \multicolumn{4}{|c|}{$\begin{array}{l}\text { *Significant at the } .001 \text { level } \\
* * \text { Significant at the } .05 \text { level }\end{array}$} \\
\hline \multicolumn{4}{|c|}{$\begin{array}{l}\text { Reference Variable for Race: White-Non Hispanic } \\
\text { Reference Variable for Sex: Male }\end{array}$} \\
\hline
\end{tabular}

The findings reveal that Sex is significant as presented in the analysis in table 1. Females are 31\% lower than males to self-report delinquency. This is similar to the findings in table 1, indicating there is little change when Race is introduced into the equation.

When analyzing race, by using multivariate logistic regression, the analysis compared all races with the reference category White. All racial groups included in the study are significant. Even when incorporating the variable of Sex, the results of a 
multivariate logistic regression for race are very similar to the bivariate regression of table 1. Hispanic /no-race specified have the strongest relationship, indicating that Hispanics are 78\% more likely to self-report delinquency than Whites. Blacks and Multiracial had the next strongest relationship. Both groups were 60\% more likely than Whites to self-report delinquency. Asians are the only racial category in table 2 to report lower rates of delinquency than Whites, with odds being 22\% less likely for Asians. Overall, this model produced a Cox \& Snell pseudo R square of .023

When analyzing Table 3, each model represents results of a hypothesis tested. The first model represents the first hypothesis; model 2 represents the second hypothesis; model 3 represents the third hypothesis, and model 4 represents the fourth hypothesis. Multivariate regression was used to analyze each model in table 3. The first model in the table 3 represents the relationship between the demographic variables, the independent variables of Negative Student Views and Rules and Regulations. The second model represents the relationship between the demographic variables, the independent variables used in model 1 and attachment and involvement. The third model represents the variables of model 2 and Negative Views and Victim. Finally, model 4 includes all the independent variables of previous models and the variable of Commitment.

Within the first model, the demographic variables of Sex and Race reveal some differences from the previous tables. The relationship between the demographic variables and juvenile delinquency is reduced when Negative Views, and Rules and Regulations are introduced into the equation. For example, females self-reporting delinquency decreased from $31 \%$ lower than males in table 2, to $27 \%$ lower than males in model 1 of table 3. 


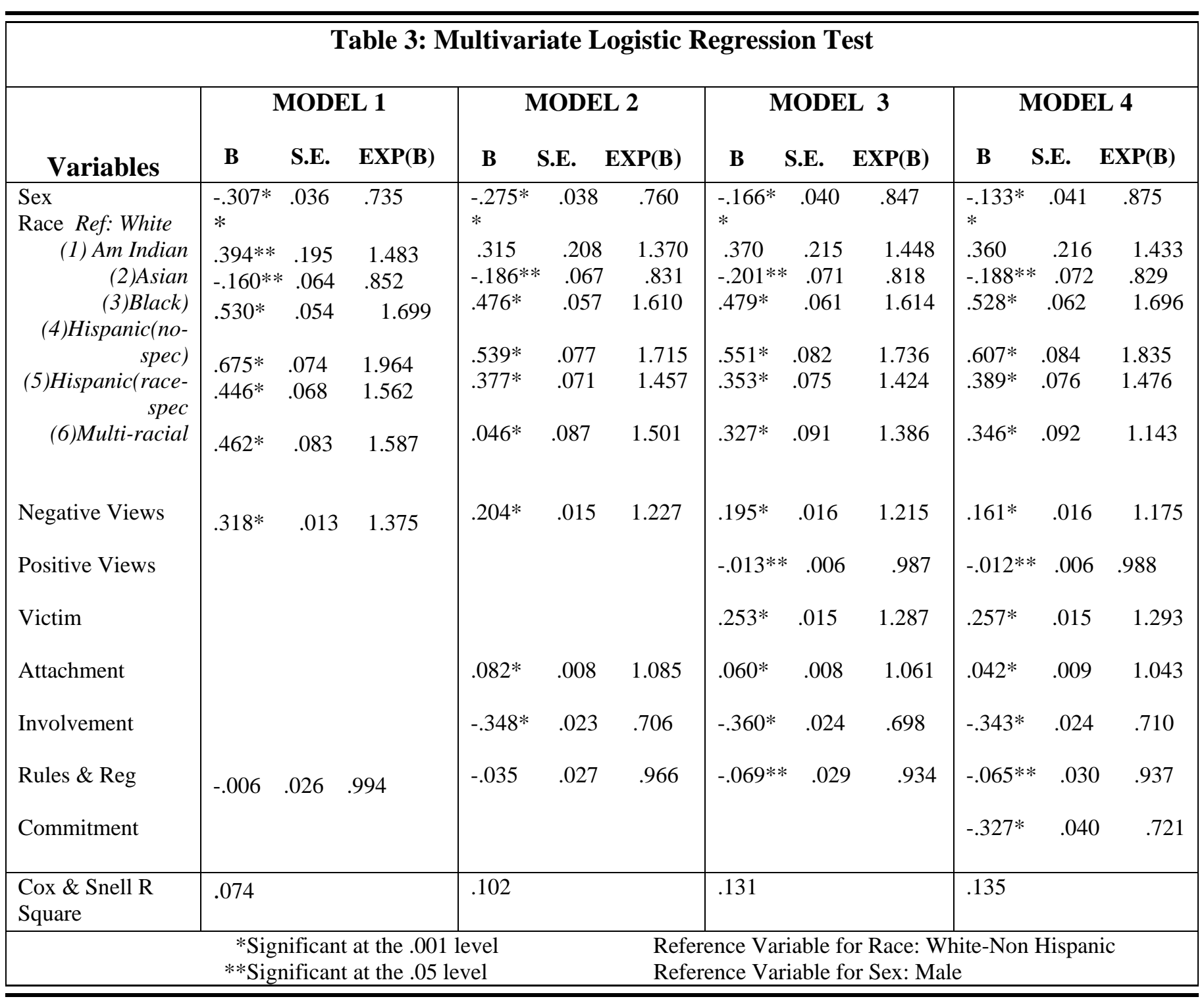

However, when the variables of Positive Views, and Rules and Regulations are introduced in the equation the variable of Race increased. For example, Blacks increased from $60 \%$ more likely to self-report delinquency than Whites in table 2 to $70 \%$ more likely to self-report delinquency than Whites in model 1, table 3 . Similarly, the odds of Hispanic/no race increased from $78 \%$ to $96 \%$ more likely to report delinquency than whites. Asians went from 22\% to 15\% decrease of reporting delinquency than whites. 
The increase relationship between Delinquency and Race is evident in the other racial categories as well. The only exception is American Indians who went from $58 \%$ to $48 \%$ more likely than Whites to report delinquency.

\section{Multivariate Analysis for Table 3}

When analyzing the variable of Sex across models, findings indicate a $16 \%$ decrease of females being more likely than males to self-report delinquency from model 1 to model 4 . The relationship between sex and delinquency becomes less meaningful from model 1 to 4 , although the relationship remains significant. For example, the odds of females being less likely to self-report delinquency than males’ decreases from $27 \%$ in model 1 to $24 \%$ in model 2 , to $15 \%$ in model 3 and finally to $13 \%$ in model 4 . The introduction of more independent variables into the equation causes sex to be less important. Sex becomes substantially less significant, even though it remains statistically significant.

When comparing the variable of race in model 1 and model 2 the results show that the odds decrease. Model 1 incorporates Positive Views, Rules and Regulations, whereas model 2 incorporates the variables of Attachment and Involvement. For example, Blacks in model 1 decrease from 70\% more likely to report delinquency than Whites are, to $61 \%$ in model 2. The relationship between Race and Delinquency also weakens in model 2 when Attachment and Involvement are added into the equation. For example, Asians, model 1 were 15\% were less likely to report delinquency than Whites are. However, in model 2 Asians were 17\% less likely than Whites to self-report delinquency. The other variables of Race for model 2 are consistent with these findings. 
However, when examining race in model 3, the coefficient and odds increase. Model 3 incorporates the previous variables of model 1 and 2 but also includes the variables of Negative Views and Victim. The results for race in table 3 show such a small increase in the odds, as to be irrelevant. For instance, Blacks in model 3 were $61 \%$ more likely than Whites are to self-report delinquency in model 2, but the odds ratio remained the same in model 3. Other race categories also increased only slightly despite being significant. Another example is Hispanic/ no-race whose odds of self-report delinquency only increased from $71 \%$ in model 2 , to $73 \%$ in model 3 when compared to Whites. This indicates that when students hold Negative Views of school and has been a victim of wrongdoing the odds for delinquency increase but not substantially. Hypothesis 1. Model 1 tests the first hypothesis that if students have Negative Views of their school life then the students will suffer from more stress, which could lead to delinquency. Controlling for demographics, results from model 1 support hypothesis 1 . Students who have Negative Views and disagree with Rules and Regulations in school are more likely to self-report delinquency. For each increment, the Negative Views scale (3 to 12) students are 37\% more likely to self-report delinquency in school.

Within model 1, the variable Negative Views is a significant (at the .05 level) relationship, when incorporating sex and race into the equation. The results from model 1 indicate support for the first hypothesis. Students who have negative views are more likely to self-report delinquency. For each increment on the Negative Views scales increases the likelihood of reporting delinquency by $37 \%$. However, it does not seem that rules and regulations altered reported delinquency. In general, the results of model 1 indicate that there is a relationship between a student's negative views of school and 
delinquency. Students' negative views increase delinquency, while there is little relationship between rules and regulations and delinquency. Overall model 1 produced a Cox and Snell pseudo R square of .074.

Hypothesis 2.

Model 2 in table 3 analyzes hypothesis 2, which asserts that if one is attached to his/her school environments and is involved in school activities then he/she is less likely to suffer from strain and thus will have less reported delinquency. Interpreting model 2 of table 3 takes into account Sex, Race, and the independent variables of model 1; Negative Views and Rules and Regulations, but also incorporates and variables of Attachment and Involvement into the equation. Analyzing model 2 indicates that Attachment and Involvement seem to decrease the odds of reported delinquency. The relationships between Attachment and Involvement with Self-Reported Delinquency are strong and significant, although the direction of the Attachment variable is positive.

Within model 2 the variable of attachment is statistically significant. Although the relationship is positive, the way the variable is coded indicates that delinquency decreases when the students agree with the indicators of Attachment. Attachment is coded as 1 strongly agree to 4 strongly disagree. For each increment of disagreement with attachment (scale of 7 to 28), students reporting delinquency increases by $8.5 \%$. Thus, going from 7 (strongly agree) to 28 (strongly disagree) on the Attachment scale a student is $178 \%$ more likely to report delinquency if they strongly disagree with Attachment to school.

When analyzing the variable of involvement in model 2, the variable is coded as 0 $=$ No and $1=$ Yes. The relationship between delinquency and involvement is a negative 
one and is significant. When students are involved in school, they are $30 \%$ less likely to be delinquent. Overall model 2 produced a Cox and Snell pseudo R square statistic of .102 .

Hypothesis 3. As in the previous two hypotheses, multivariate analysis was used to examine hypothesis 3 that states if students who have been victimized at school coupled with Negative Views of their school causes emotional strain for the students that will lead to a greater likelihood of juvenile delinquency. Table 3 depicts the multivariate results of the demographic variables of sex, and race and the independent variables of Positive Student Views, Rules, Attachment, and Involvement. Added into this equation are the variables of Positive Views and Victim. Taking all of these independent variables into account reveals that the more a student disagrees with variable of positive views and the more they agree with the variable of victim increases the likelihood of delinquency.

An Examination of model 3 reveals that the relationship for Positive Views is significant at the .001 level. The direction of the relationship between Positive Views and Self-Reported Delinquency is a negative one, which indicates that $1 \%$ is more likely to self-report delinquency when they disagree with Positive Views. The range of scores is 9 to 36, 36 being high Positive Views and 9 being low Positive Views. Going from 9 to 36 student self- reported delinquency would decrease $27 \%$.

The variable of victim is a positive and significant relationship. The relationship is not very strong, however despite the level the relationship reveals that students being 28\% more likely to be delinquent if they had been victimized at school. Overall model 3 produced a Cox and Snell R square statistic of .131 
Hypothesis 4. Like the previous three hypothesis, the researcher used multivariate analysis to examine hypothesis 4 states if student's Positive Views of school and students Commitments to school ease a students' social strain and thus contributes to a decrease in student delinquency. Table 3 depicts the multivariate results of the demographic variables of Sex, and Race and the independent variables of positive student views, rules, Attachment, and Involvement, Negative Views and Victim. Included in the final equation of model 4 is the variable of Commitment, which is coded as (1) Not at All (2) Somewhat (3) A Great Deal. From Not At All Committed, to Committed A Great Deal, the odds decrease $56 \%$ that a respondent will report juvenile delinquency.

When analyzing model 4, the variable of Commitment is a negative relationship and is significant at the .001 level. The relationship between the dependent variable of Delinquency and the independent variable of Commitment reveals a somewhat strong relationship, with students being $28 \%$ less likely to commit delinquency if they like school a great deal. Therefore, if students who have enjoy school more are less likely to be delinquent. However, although Commitment is statistically significant it is so small, that it is not substantial. Overall, model 4 produced a Cox and Snell R square statistic of .135.

Overall Findings of Multivariate Analysis. When comparing the overall findings of each independent variables of each model, there are certain trends that become evident as seen in the coefficients and the odds ratio. First, the values of the variable of Negative Views continually decrease from model 1 to model 4 as other variables are incorporated. Therefore, the more an individual disagrees with Negative Views, the less likely they are to report delinquency. In model 1 the odds are $37 \%$ less likely to self-report delinquency. 
In model 2, if students disagree with negative views they are 22\% less likely, in model 3, $21 \%$ and in model 4, 17.5\% less likely to self-report delinquency. Therefore, the more indicators added into the equation the less likely students would self-report delinquency.

The variables of Rules and Regulations, and Involvement are both negative in terms of direction. Unlike Negative Views, Rules and Regulations do not consistently reduce throughout the four models. In model 3, students reporting delinquency increase to $6 \%$ for each increment, when the variables of Positive Views and Victim are introduced in the equation. Furthermore, when the variable Commitment is introduced in model 4, the variable of rules remains at 6\%. Similarly, the odds of Involvement remain virtually unchanged from $30 \%$ in model 2 , to $29 \%$ in model 4 .

In contrast to the previous variables, the odds students who disagree with positive views $(\operatorname{Exp}\{\boldsymbol{B}\}=1 \%)$ remain unchanged from model 3 to model 4. Nevertheless, both numbers are significant at the .001 level. Furthermore, the odds of victim only increases from $28 \%$ in model 3 , to $29 \%$ in model 4 , with both being significant at the .05 level. DISCUSSION AND CONCLUSION

The purpose of this study is to test Robert Agnew's General Strain Theory and determine whether this theory is applicable to the subject of school delinquency and misconduct. The purpose of this study was to test General Strain Theory. The data set used was the ELS 2002 base-year. The reason the researcher constructed variables into the Social Bond categories (attachment, involvement, belief, and commitment) was simply based on Agnew's notion that psychological strain was caused by a social environment that worked against a person's desire to belong and thrive. The variables available for this study happen to fit the categories of social bond theory. Results from 
this study indicate that there are sources of strain. By strain, the study is describing negative treatment from others that results in anger and frustration that could lead to individual deviance (Agnew 1997: 31). Overall, the results of the study show sources of strain that support Agnew’s theory.

The causes of strain include the loss of positively valued stimuli, failure to achieve positive stimuli, and presentation of negative stimuli. Types of strain that the study focuses on are negative stimuli and the loss of positively valued stimuli (Agnew 1994: 425). Loss of positive stimuli may be defined as the loss of something value (an example would be a relationship) which could lead to delinquency if the individual is trying to prevent the loss (Agnew 1994: 425). In the research, the loss of positively valued stimuli is represented as the variable victimization. The presentation of negative stimuli is the adverse relations that an adolescent might face, such as bad relations with parents, teachers, peers and negative school experiences (Agnew 1994: 425). Negative stimuli are represented as the variable negative student views (Agnew 1994: 425).

Robert Agnew described two different ways to determine strain theory. First, a subjective approach in which the researcher asks the respondent if they like the way they are treated. The second approach is objective in which a researcher asks a respondent about the pre-determine causes of strain that the research has already identified (Agnew 2000). This study utilizes both methods Agnew suggests to measure strain. The questions concerning student views and beliefs subjectively measure strain, and the questions concerning whether the student has been a victim measure predetermined sources of strain. Furthermore, because the researcher scaled questions in the survey 
from least to greatest or by agreement, it gave some indication as to the repetitiveness of strain.

The results reveal support for strain and corroborate all four hypotheses. When analyzing the four hypotheses individually, the study makes the assumption that strain does cause delinquency. In hypothesis 1 , should students hold negative views (disagreement with Negative View index) of their school life, then the students will likely suffer from greater strain which would likely lead to delinquency. According to Agnew's theory, strain should rise because of agreement with Negative Views and disagreement to Rules and Regulations cause negative stimuli. The findings indicate that Negative Views increase when controlling for sex and race in the equation. Therefore, one must conclude students experiencing repetitive strain will lead to delinquency.

In hypotheses 2, if students are attached to their school environments and are involved in school activities, then they are less likely to suffer from strain, and thus will have less reported delinquency. On the other hand, students who strongly disagree with the questions of attachment are more likely to self-report delinquency. This indicates that the more students agree with Attachment index, the less likely to report delinquency. One can conclude that if students feel as though they belong in school, they can better cope with strain. In addition, if students are involved in activities they are less likely to report delinquency. Thus, a students' involvement (agreement with Involvement index) in school activities reduce feelings of strain.

In hypothesis 3, in which students who have a disagreement with Positive Views of school should result in more strain, however if students have been a victim (agreement with Victim index) of school delinquency, there is a greater chance of the student 
experiencing strain and thus being delinquent in school. Victimized students' repeatedly show a source of strain, since an individual cannot always control being a target of wrongdoing. The best solution would be to resolve crime. Without any coping mechanisms, strain resulting from being a victim can lead to delinquency.

Hypothesis 4, indicate that if students have positive views and are committed (agree a great deal to Commitment index) to their school, then they are less likely to commit delinquency. Thus, students who are involved in school and who conform to school rules and expectations are less likely to experience strain. Overall, examination the four models indicates that the more students' are conventionally bonded to school, the less likely they are to experience strain to the same degree. These models are consistent with previous research concerning Agnew's theory. Negative views are a cause of Subjective Strain that could lead to delinquency. Victimization is a cause of Objective Strain that could also potentially lead to delinquency.

Sex remained statistically significant in the study, yet became less substantive as other variables were brought into the equation. The results as seen in the results are parallel to what Agnew maintains; males are most likely to act out delinquently when they experience strain. According to Agnew, females are likely to experience different strain or have a different response from the same strain as males (Agnew and Broidy 1997: 281-283). However, in the study, sex became less meaningful in the multivariate analysis, thus indicating that there is not such a large difference between men and women and delinquency. The study may have been limited in that; the study did not investigate directly the different types of strain males and females experience separately. This 
demonstrates that there should be more research on male versus female strain and delinquency.

The study also reveals differences between race and delinquency. First, minority students (with the exception of Asian students) are more likely than whites are to be delinquent in school. However, there is little explanation in Robert Agnew's research concerning differences in race. However, it should be noted that a limitation of this study is that it did not take into account background factors such the student's neighborhood (whether the student lives in a neighborhood with a lot of crime), the students' background, and influence of their parents (whether a parent has been incarcerated). Since this study does not take into account such questions, it is difficult to understand why minority students are disproportionately more likely to be delinquent in schools. Furthermore, Agnew's research provides little discussion of race and determinants of delinquent behavior. Agnew's possible explanation for these issues would be his discussion of coping strategies for strain. Agnew maintains that coping strategies allow an individual to deal with factors of strain in a cognitive, emotional and behavioral way without having to resort to crime. (Agnew 1992). However, the study's indicators do not probe what coping strategies students have directly for avoiding delinquency. Instead, the researcher assumed strain avoidance through the indicators of attachment, involvement and positive views. Overall, there needs to be greater explanation between strain, and delinquency when concerning race and ethnicity.

The research did not examine possible coping mechanisms for strain per se. The research did analyze those students with positive views of school, involvement and commitment to school. However, the analysis did not account for teachers, and parents' 
viewpoints, or students' backgrounds, which could contribute to strain. It is difficult to measure all the possible causes of strain because it is difficult to find a data set that accommodates Agnew's entire hypothesis to be tested (Agnew and White 1992: 478).

In conclusion of this study, the research has shown that students, who are more involved, committed, and who respond favorably in school, are less likely to engage in delinquency. Students, who lack the above qualities, will need to develop coping mechanisms to help ease feelings of stress in school. Instituting programs or counseling may be the key to mitigating juvenile delinquency in schools. The key to easing strain is reaching out to students and getting them involved with social networks. Schools could develop resources for students who experience disconnection in school. Such programs could potentially ease strain, since according to Agnew; students who have social supports are less likely to participate in delinquency and crime.

In addition, there is a need for more research on strain theory. Although Robert Agnew's theory has sparked a new interest in strain, more research concerning stress is needed to explain questions of sex and race. Previous research on strain has used small data sets. It would be worthwhile to explore the cause of strain using larger and more encompassing data, which would allow for an understanding as to how strain affects different groups, and what coping strategies different groups use.

\section{REFERENCES}

Agnew, Robert, Timothy Brezina, John Paul Wright, and Francis Cullen. (2002). "Strain, Personality Traits, and Delinquency: Extending General Strain Theory. Criminology 40(1) 43-63

. Robert, Cesear Rebellon, and Sherod Thaxton. (2000). "A General Strain Theory Approach to Families and Delinquency.” Families, Crime and Criminal Justice, 2 , 113-138 
. Robert (1997a). The nature and Determinants of Strain: Another Look at Durkheim and Merton. In Agnew, Robert and Nikos Passas (eds.). The Future of Anomie Theory. (pp.27-51). Boston: Northeastern University Press.

. Robert and Lisa Broidy. (1997). Gender and Crime: A General Strain

Perspective. Journal of Research in Crime and Delinquency. 34(3), 275-306

. Robert, and Helene Raskin White. (1992). "An Empirical Test of General Strain Theory.” Criminology. 30(4). 476-499

. Robert, and Sandra Huguley. (1989) “Adolescent Violence toward Parents” Journal of Marriage and the Family 51 (3) 699-711.

. Robert. (1985). “A Revised Strain Theory of Delinquency.” Social Forces, 64 (1) 151-167.

Aselhine, Jr, Robert H, Susan Gore, Jennifer Gordon (2000) “Life Stress, Anger and Anxiety, and Delinquency: An Empirical Test of General Strain Theory.” Journal of Health and $\quad$ Social Behavior. 41 (September) 256-275.

Baron, Stephen W. (2004) “General Strain, Street Youth and Crime: A Test of Agnew’s Revised Theory” Criminology. 42(2), 457-480.

Creswell, John W. (2003). Research Design: Qualitative, Quantitative, and Mixed Methods. $2^{\text {nd }}$ ed. Thousand Oaks: Sage Publications

Farnsworth, Margaret, and Michael J. Leiber. (1989). “ Strain Theory Revisited: Goals, Educational Means, and Delinquency.” American Sociological Review. 54(2) 263274

Felson, Richard, and Allen E. Liska, and Scott J. South, and Thomas L. McNulty.(1994). "The Subculture of Violence and Delinquency: Individual vs. School Context Effects.” Social Forces 73(1), 155-173

Foshee, Vangie and Karl E. Bauman. (1992). "Parental and Peer Characteristic as Modifiers of the Bond-Behavior Relationship: An Elaboration of Control Theory.” Journal of Health and Social Behavior. Vol 33 no 1. 66-76.

Giddens, Anthony, Mitchell Duneier, and Richard P. Appelbaum. (2003). Introduction to Sociology $4^{\text {th }}$ ed. New York: W.W. Norton and Company, Inc.

Giordano, Peggy C., Stephen A. Cernkovich, Theodore Groat, M.D Pugh, Steven P. Swinford. (1998). “The Quality of Adolescent Friendships: Long Term Effects?” Journal of Health and Social Behavior. 39 (1) 55-71. 
Hirschi, Travis. (1969). Causes of Delinquency. Berkeley: University of California Press.

Hoffman, John P. and Felicia Gray Cerbone (1999). "Stressful Life Events and Delinquency Escalation in Early Adolescence.” Criminology. 37(2) 343-371.

. John P. and S. Susan Su. (1997). "The Conditional Effects of Stress on Delinquency and Drug Use: A Strain Theory Assessment of Sex Differences.” Effects of Stress. 34(1), 46-78

Ingels, Steven J., Laura J. Burns, Stephanie Charleston, Xiangeli Chen, Emily Forrest Cataldi, and Jeffery Owens. (2005). "A Profile of the American High School Sophomore in 2002: Initial Results From the Base Year of the Longitudinal Study of 2002" National Center of Educational Statistics. United States Department of Education. 1-148.

. Michael Planty, and Robert Bozick. (2005). "A Profile of the American High School Senior in 2004: A First Look. Initial Results From the First Follow-up of the Education Longitudinal Study of 2002." National Center of Educational Statistics. United States Department of Education. 1-95.

. Leslie Scott, and Jeffery Owens. (2004). “The High School Class of 2002: A Demographic Description. First Year Results of the Base Year of Educational Longitudinal Study 2002.” National Center for Educational Statistics. United States Department of Education. 1-59.

Jenkins, Patricia H. (1995). “School Delinquency and School Commitment.” Sociological of Education. 68 (3) 221-239.

Johnson Jr, William A., Richard P Retting, Gregory M. Scott, and Stephen M Garrison. (2004). The Sociology Student Writer's Manual. $4^{\text {th }}$ ed. New Jersey: Person

Joseph, Janice. (1996). "School Factors and Delinquency: A Study of African American Youths.” Journal of Black Studies. 26(3). 340-355.

Kaplan, Howard B., Robert J. Johnson and Carol A. Bailey. (1987). "Deviant Peers and Deviant Behavior: Further Elaboration of a Model.” Social Psychology Quarterly. Vol.50 No. 3 (Sep. 1987). 277-284.

Krohn, Marvin D., James L. Massey, William F. Skinner, and Ronald M. Lauer. (1983). Social Bonding Theory and Adolescent Cigarette Smoking: A Longitudinal Analysis.” Journal of Health and Social Behavior. 24(4) 337-349.

Matsueda. Ross L. (1989). “The Dynamics of Moral Beliefs and Minor Deviance.” Social Forces. 68(2) 428-457.

. Ross L. (1982). "Testing Control Theory and Differential Association: A Causal Modeling Approach.” American Sociological Review. 47 (4) 489-504. 
Meier, Robert F. (1982). "Perspectives on the Concept of Social Control.” Annual Review of Sociology. 8 35-55

Merton, Robert K. (1938). “Social Structure and Anomie.” American Sociological Review. 3(5) 672-682.

Osgood, D. Wayne, Janet K. Wilson, Patrick M. O’Malley, Jerald G. Bachman, Lloyd D. Johnston. (1996). "Routine Activities and Individual Behavior." American Sociological Review. 61(4) 635-655.

Piquero, Nicole Leeper and Miriam D. Sealock. (2000). "Generalizing General Strain Theory: An Examination of an Offending Population.” Justice Quaterly. 17(3) 449-484.

Sampson, Robert J. and John H. Laub. (1990). "Crime and Deviance over the Life Course: The Salience of Adult Social Bonds. American Sociological Review 55(5) 609-627.

Sets, Jan E. and Peter J. Burke. (2000). "Identity Theory and Social Identity Theory." Social Psychology Quarterly. Vol 63. No. 3. 224-237

Taylor, Paulette B., Philip L. Gunter, and John R. Slate (2001). “Teachers’ Perceptions of Inappropriate Student Behavior and Students' Gender and Ethnic Background” Behavioral Disorders 26(2) 146-151.

Tulley, Michael, and Lian Hwang Chiu. (1995). "Student Teachers and Classroom Discipline.” Journal of Education Research. 88(3) 164-171.

Wiatrowski, Michael D., David Griswold, and Mary K. Roberts. (1981). "Social Control and Delinquency.” American Sociological Review 46(5) 525-541.

Williams-Evans, and A. Shiphrah. (2004). “Adolescent Violence.” ABNF Journal. 15(April) 1-5

Zhang, Lening, and Steven F. Messner. (1996). "School Attachment and Official Delinquency Status in the People's Republic of China. Sociological Forum. 11 (2). 285-303.

Webpage

(2003) http://www.criminology.fsu.edu/crimtheory/agmew.htm

Webpage

(2006). Retrieved from

<"http://en.wikipedia.org/wiki/Strain_theory_\%28sociology\%29">

Webpage 
Demelo, Diane (2006). Retrieved from<"http://home.

comecast.net/ ddemelo/crime/hirschi.html”>

\section{Webpage}

(2005). <www.hewett.norfolk.sch.uk/curric/soc/crime/mert_str.htm: 2005>

Webpage

(2006). Retrieved

from<"http://home.comecast.net/ ddemelo/crime/hirschi.html”>

Webpage

(2005). <www.hewett.norfolk.sch.uk/curric/soc/crime/mert_str.htm: 2005> 


\section{Appendix A}

Variable Labels

Description of variables and their indicators

\section{INDEPENDENT VARIABLES}

Positive Student Views of School (Belief)

(1) BYS27G 'Learns skills for job in school'

(2) BYS27B 'Satisfied by doing what expected in class'

(3) BYS27D 'Education is important to get a job later'

(4) BYS21B 'School rules are fair'

Negative Student Views of School (Belief)

(1) BYS20H 'In class often feels put down by teachers'

(2) BYS20I 'In class often feels put down by students'

(3) BYS20J 'Does not feel safe at this school'

(4) BYS20K 'Disruptions get in way of learning'

(5) BYS20L 'Misbehaving students often get away with it'

(6) BYS20M 'There are gangs in school'

(7) BYS20N 'Racial/ethnic groups often fight'

(8) BYS27C 'Has nothing better to do than school'

(9) BYS20D 'Other students often disrupt class'

Student Attachment

(1)BYS20A 'Students get along well with teachers'

(2)BYS20E 'The teaching is good'

(3)BYS20F 'Teachers are interested in students'

(4)BYS20G 'Teachers praise effort'

(5)BYS27F 'Plays on a team or belongs to a club'

(6)BYS27H 'Teachers expect success in school'

(7)BYS27I 'Parents expect success in school'

Academic Support (Involvement)

(1)BYS23A 'Won an academic honor'

(2)BYS23C 'Recognized for good grades'

Rules and Regulations

(3)BYS21D 'School rules are strictly enforced'

Victim

(1)BYS22A 'Had something stolen at school'

(2)BYS22B 'Someone offered drugs at school'

(3)BYS22C 'Someone threatened to hurt 10th grader at school'

(4)BYS22E 'Someone hit 10th grader' 
(5)BYS22F 'Someone forced money/things from 10th grader'

(6)BYS22H 'Someone bullied or picked on 10th grader'

\section{Commitment}

(1)BYS28 'How much likes school'

\section{DEPENDENT VARIABLES}

Student Self-Reported Delinquency

(1) BYS24A 'How many times late for school'

(2) BYS24B 'How many times cut/skip classes'

(3) BYS24C 'How many times absent from school'

(4) BYS24D 'How many times got in trouble'

(5) BYS24E 'How many times put on in-school suspension'

(6) BYS24F 'How many times suspended/put on probation'

(7) BYS24G 'How many times transferred for disciplinary reasons' 